\title{
Peptide Bond Formation by Using 2-Pyridyl Thio Esters
}

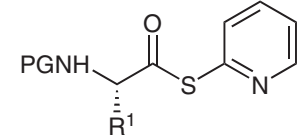

A (1.0 equiv)<smiles>[R]C(N)C(=O)O[Na]</smiles>

B ( 1.25 equiv)

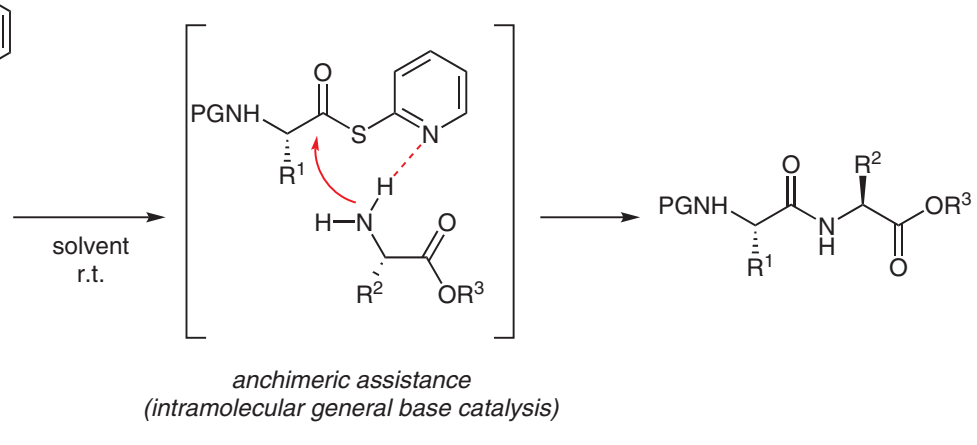<smiles>CCOC(=O)CNC(=O)CNC(=O)OCc1ccccc1</smiles>

DMF, 5 min $90 \%$ yield<smiles>CC(C)C[C@H](NC(=O)OCc1ccccc1)C(=O)N[C@@H](CCC(=O)OCc1ccccc1)C(=O)OCc1ccccc1</smiles>

EtOAc, $30 \mathrm{~min}$ $84 \%$ yield<smiles>CC[C@H](C)[C@H](NC(=O)[C@@H](NC(=O)OC)C(C)C)C(=O)OC</smiles>

dioxane, $60 \mathrm{~min}$ $89 \%$ yield<smiles>CC[C@H](C)[C@H](NC(=O)[C@@H](NC(=O)OCc1ccccc1)C(C)C)C(=O)OC</smiles>

DMF, $10 \mathrm{~min}$

$84 \%$ yield<smiles>COC(=O)C(NC(=O)[C@H](CCSC)NC(=O)OCc1ccccc1)C(C)C</smiles>

DMF, 5 min

$85 \%$ yield<smiles>CC[C@H](C)[C@H](NC(=O)[C@@H](NC(=O)OC)C(C)C)C(=O)OC</smiles>

\section{Key words}

peptide bond formation

pyridyl thio esters

anchimeric assistance<smiles>CCC(C)[C@H](NC(=O)OCc1ccccc1)C(=O)N[C@H](C(=O)OC)C(C)C</smiles><smiles>CCOC(=O)CNC(=O)[C@H](Cc1c[nH]c2ccccc12)NC(=O)OCc1ccccc1</smiles>

\section{DMF, 5 min} $77 \%$ yield<smiles>CCC(C)[C@H](NC(=O)OC(C)(C)C)C(=O)NC(C(=O)OC)C(C)C</smiles>

Significance: Anchimerically assisted coupling methods have been used in peptide synthesis. These reactions usually start from active esters, such as 8-hydroxyquinoline esters or o-methoxyphenyl esters. In 1971, Lloyd and Young reported a method that used active 2-pyridyl thio esters and amines to form peptide bonds with anchimeric assistance.
Comment: With the 2-pyridyl thio esters, various dipeptides can be synthesized without the use of classical peptide-coupling reagents. The yields of the target peptides are moderate to excellent, and the reaction time is short. 